\title{
COMPARISON OF DIFFERENT DIAGNOSTIC GUIDELINES FOR THE DIAGNOSIS OF MACROPHAGE ACTIVATION SYNDROME COMPLICATING SYSTEMIC JUVENILE IDIOPATHIC ARTHRITIS: SINGLE CENTRE EXPERIENCE
}

\author{
Marija Jelušić, Matea Kronja, Marijan Frković, Saša Sršen, \\ Sanda Huljev Frković and Ksenija Štekić Novački \\ Department of Pediatrics, Zagreb University Hospital Centre, \\ University of Zagreb School of Medicine, Zagreb, Croatia
}

\begin{abstract}
SUMMARY - Macrophage activation syndrome (MAS) is a potentially fatal complication of systemic juvenile idiopathic arthritis (sJIA), caused by exaggerated but ineffective immune response. The aim of the study was to compare the capacity of the HLH-2004 guidelines with the capacity of the MAS guidelines from 2005, and with the new set of classification criteria from 2016 in diagnosing MAS complicating sJIA. The study included 35 children aged 1-18 diagnosed with sJIA according to ILAR criteria and treated at the Department of Pediatrics, Division of Immunology and Rheumatology, Zagreb University Hospital Centre, in the period from 2009 to 2015. Out of 35 patients diagnosed with sJIA, there were 12 girls and 23 boys, with the mean age at disease onset $( \pm$ SD) $5.51 \pm 3.65$ years. Eight patients had flare of disease. With the guidelines from 2005, MAS was diagnosed in six (17.1\%) patients with sJIA. With the new set of classification criteria from 2016, MAS was diagnosed in four (11.4\%) patients with sJIA. MAS was not diagnosed with the HLH-2004 guidelines. In our study, four out of six patients had MAS at the onset of sJIA, and in the rest two it occurred during relapse. Two patients with MAS developed full-blown clinical picture while another four had incomplete clinical features with minor laboratory alteration. Due to the use of different diagnostic guidelines, we found difference in the prevalence of MAS. It was slightly higher in comparison to available studies, while other researched features, such as clinical characteristics, were similar.
\end{abstract}

Key words: Macrophage Activation Syndrome; Arthritis, Juvenile; Child; Croatia; Lymphohistiocytosis, Hemophagocytic

\section{Introduction}

Macrophage activation syndrome (MAS) is a potentially fatal complication of systemic juvenile idiopathic arthritis (sJIA), caused by an exaggerated but ineffective immune response involving excessive mac-

Correspondence to: Assoc. Prof. Marija Jelušiç, $M D, P h D$, Department of Pediatrics, Division of Pediatric Rheumatology and Immunology, Referral Centre for Pediatric Rheumatology, Zagreb University Hospital Centre, Kišpatićeva 12, HR-10000 Zagreb, Croatia

E-mail: marija.jelusic.drazic@gmail.com

Received June 27, 2016, accepted September 12, 2016 rophage and $\mathrm{T}$ cell activation, followed by high production of proinflammatory cytokines ${ }^{1-3}$. The cardinal clinical symptoms and signs are prolonged high fever, hepatosplenomegaly, neurologic dysfunction, and hemorrhagic manifestations. Characteristic laboratory abnormalities include pancytopenia, elevated levels of serum liver enzymes, triglycerides, lactate dehydrogenase, ferritin, and low levels of fibrinogen. Although macrophage hemophagocytosis is often seen on bone marrow examination, in the initial stages of the syndrome this finding may be absent $t^{4,5}$. The reported mortality rates of MAS reach $20 \%-30 \%$, but the outcome can be improved by early diagnosis and prompt initia- 
tion of life-saving treatment ${ }^{3}$. The estimated prevalence of MAS in sJIA is $10 \%$. However, recent evidence suggests that the syndrome may occur subclinically in an additional 30\%-40\% of sJIA patients ${ }^{6,7}$. Because MAS is similar to the group of histiocytic disorders belonging to hemophagocytic lymphohistiocytosis (HLH), it is currently classified among the secondary, or acquired, forms of $\mathrm{HLH}^{8,9}$. Three sets of guidelines are currently available for diagnosing MAS in patients with sJIA, as follows: diagnostic guidelines for HLH (HLH-2004), which were primarily developed for homozygous genetic disorders ${ }^{10}$; preliminary diagnostic guidelines for MAS complicating sJIA from 2005 ${ }^{11}$; and the new set of classification criteria for MAS complicating sJIA from 2016, based on a combination of expert consensus, available evidence from medical literature, and analysis of real patient data $^{12}$.

\section{Patients and Methods}

A retrospective study was carried out at the Department of Pediatrics, Division of Immunology and Rheumatology, Zagreb University Hospital Centre, in the period from 2009 to 2015 . The study included 35 children aged 1-18 diagnosed with sJIA according to ILAR criteria $^{13}$. Epidemiological and clinical data were obtained from patient records. Demographic information included gender, date of birth, age at onset of sJIA and age at onset of MAS. Clinical data included fever, hepatomegaly, splenomegaly, hemorrhagic manifestations, lymphadenopathy, active arthritis, central nervous system (CNS) involvement and serositis. Extensive laboratory workup was performed on all patients (erythrocyte sedimentation rate (ESR), C-reactive protein (CRP), complete blood count, aspartate aminotransferase (AST), alanine aminotransferase, fi-

Table 1. Clinical features and laboratory values of patients with systemic juvenile idiopathic arthritis (sJLA), in sJLA flare, and in patients with macrophage activation syndrome (MAS) complicating sJLA

\begin{tabular}{|c|c|c|c|}
\hline & $\begin{array}{l}\text { Onset of sJIA } \\
\mathrm{n}(35)\end{array}$ & $\begin{array}{l}\text { Flare of sJIA } \\
\mathrm{n}(8)\end{array}$ & $\begin{array}{l}\text { Systemic JIA with MAS } \\
\mathrm{n}(6)\end{array}$ \\
\hline Fever & $35 / 35$ & $8 / 8$ & $6 / 6$ \\
\hline Arthritis & $35 / 35$ & $6 / 8$ & $1 / 6$ \\
\hline Evanescent rash & $35 / 35$ & $8 / 8$ & 0 \\
\hline $\begin{array}{l}\text { Generalized } \\
\text { lymphadenopathy }\end{array}$ & $2 / 35$ & 0 & 0 \\
\hline Hepatomegaly & $8 / 35$ & $4 / 8$ & $5 / 6$ \\
\hline Splenomegaly & $4 / 35$ & $1 / 8$ & $1 / 6$ \\
\hline Serositis & $3 / 35$ & 0 & $1 / 6$ \\
\hline Hemorrhages & 0 & 0 & $1 / 6$ \\
\hline CNS involvement & 0 & 0 & 0 \\
\hline $\mathrm{CRP}(\mathrm{mg} / \mathrm{L})$ & $132.2(31.7-320.8)$ & $59(25-124)$ & $123(65-431.4)$ \\
\hline $\operatorname{ESR}(\mathrm{mm} / \mathrm{h})$ & $81(32-142)$ & $39(25-70)$ & $27.5(14-55)$ \\
\hline Hemoglobin (g/dL) & $108(77-130)$ & $118(87-128)$ & $105(87-127)$ \\
\hline $\mathrm{WBC}\left(\mathrm{x} 10^{9} / \mathrm{L}\right)$ & $16.6(9.6-44.8)$ & $13.8(7.6-24.8)$ & $6.1(4.0-7.4)$ \\
\hline Platelets (x109/L) & $436(275-868)$ & $322(204-371)$ & 177 (124-271) \\
\hline Fibrinogen (g/L) & $6.7(5.1-8.4)$ & $5.5(3.6-6.2)$ & $3.3(2.1-4.2)$ \\
\hline D-dimer (mg/L) & $2.8(0.8-14.2)$ & $2.3(0.33-5.9)$ & $5.5(1.4-45.6)$ \\
\hline Ferritin $(\mu \mathrm{g} / \mathrm{L})$ & $412(129.9-9843)$ & $570(173.7-11229)$ & $3531(783-20000)$ \\
\hline $\operatorname{AST}(\mathrm{U} / \mathrm{L})$ & $28(15-61)$ & $42(15-74)$ & $66(26-210)$ \\
\hline Triglycerides (mmol/L) & $1.30(0.53-1.87)$ & $1.29(1.18-1.90)$ & $2.09(1.29-3.92)$ \\
\hline
\end{tabular}

$\mathrm{CNS}=$ central nervous system $; \mathrm{CRP}=\mathrm{C}$-reactive protein; $\mathrm{ESR}=$ erythrocyte sedimentation rate; $\mathrm{WBC}=$ white blood cell count; AST $=$ aspartate aminotransferase 
brinogen, D-dimer levels, ferritin, triglycerides, and immunologic parameters including anti-nuclear antibodies by indirect immunofluorescence and rheumatoid factor). Quantitative data are presented as median with interquartile range, and categorical data are presented as absolute number. An Ethics Committee approval was obtained before data collection.

\section{Results}

Systemic JIA was diagnosed in 35 children, 23 boys and 12 girls, mean age $( \pm$ SD) $5.51 \pm 3.65$ years. Eight of 35 patients had flare of sJIA. At the disease onset, all patients presented with fever, evanescent rash and arthritis. The most consistent symptoms were hepatomegaly (8/35) and splenomegaly (4/35). All patients with flare of sJIA also presented with fever and evanescent rash, and half of them had hepatomegaly. Inflammation markers (ESR and CRP) were elevated in all patients at disease onset and in flare (Table 1).

With the use of guidelines from 2005, MAS was diagnosed in six $(6 / 35,17.1 \%)$ patients with sJIA. In four of them, it occurred at the onset of sJIA during first hospitalization and in the remaining two patients, it occurred during flare. With the new set of criteria from 2016, MAS was diagnosed in four $(4 / 35,11.4 \%)$ patients with sJIA. In three of them, it occurred during first hospitalization, and in one patient it occurred during flare. MAS was not diagnosed with the HLH2004 guidelines. Fever (6/6) and hepatomegaly (5/6) were the most common clinical criteria recorded in patients with MAS, followed by splenomegaly and hemorrhages. CNS dysfunction was not recorded. All laboratory values were abnormal, as expected (showing either increased or decreased levels) in patients with MAS when compared with sJIA patients (Table 1).

\section{Discussion}

We compared the capacity of HLH-2004 guidelines with the capacity of MAS guidelines from 2005, and with the new ones from 2016 as diagnostic tools for MAS associated with sJIA. With the new set of criteria from 2016, the prevalence of MAS was $11.4 \%$ (4/35) and with the guidelines from 2005 the prevalence of MAS was 17.1\% (6/35). HLH-2004 guidelines did not record MAS at all. This is consistent with literature data where the prevalence of MAS in sJIA is $10 \%$, and with recent evidence suggesting the possibility of subclinical occurrence in an additional 30\%-40\% of sJIA patients ${ }^{6,7}$.

Macrophage activation syndrome generally develops in earlier phases of the underlying disease, or may be the presenting manifestation of sJIA. In our study, four out of six patients had MAS at the onset of sJIA, during first hospitalization, and in two out of six patients it occurred during flare.

Typically, patients with MAS become acutely ill with sudden onset of nonremitting high fever, profound depression in all 3 blood cell lines (i.e. leukopenia, anemia and thrombocytopenia), hepatosplenomegaly, lymphadenopathy, and elevated serum liver enzyme levels. In our study, two of 35 patients had full-blown clinical picture of MAS, with laboratory test values in line with expectations, showing absolute decline and typical changes that occur in the syndrome. Another four of 35 patients had incomplete clinical features and relative decline in these laboratory parameters in comparison with sJIA patients.

Clinical symptoms are often delayed or similar to confusable conditions such as infections, sepsis and flare of underlying disease. Comparing the criteria, it is obvious that the majority of our patients satisfied the criteria from 2005, which include clinical manifestations such as hepatomegaly and hemorrhages. Notably, five out of six patients with MAS had hepatomegaly. However, hepatomegaly was present in half (4/8) of patients with sJIA flare and in eight $(8 / 35)$ patients at the onset of sJIA, probably because mild hepatomegaly is a frequent feature of active sJIA.

The prevalence of all laboratory MAS criteria was much greater in patients with MAS comparing to sJIA. Hyperferritinemia is an important laboratory hallmark of MAS, therefore, it is mandatory in the new set of classification criteria (ferritin $>684 \mathrm{ng} / \mathrm{mL}$ ). In our study, patients with MAS had significantly increased ferritin levels; they all met the previously mentioned condition, whereas patients at the onset of sJIA and flare of sJIA did not. In the new set of MAS criteria, platelet count and fibrinogen levels are within the normal range of laboratory tests and the levels of AST and triglycerides are only slightly above the normal limits. In contrast, children with active sJIA usually have significantly increased platelet counts and fibrinogen levels, and normal levels of AST and triglycer- 
ides ${ }^{12,14}$. In our study, most of the MAS patients had slightly decreased platelet count, slightly increased AST and triglycerides, while the levels of fibrinogen and leukocytes were within the normal range.

Our results should be interpreted in the light of some potential limitations, primarily the small number of MAS patients. However, we would like to point out that we were dealing with the disease that is not considered common. Patient data were collected through retrospective review of clinical charts. We had incomplete laboratory data for triglycerides and fibrinogen, which both are part of the guidelines.

In conclusion, due to the use of different diagnostic guidelines, we found a difference in the prevalence of MAS. It was slightly higher in comparison to available studies, while other investigated features, such as clinical characteristics, were similar. It is important to make a timely diagnosis of MAS, usually by clinical expert opinion and detection of subtle laboratory alteration before the occurrence of full-blown clinical picture which, if untreated, leads to fatal outcome.

\section{References}

1. Ravelli A, Grom AA, Behrens EM, Cron RQ. Macrophage activation syndrome as part of systemic juvenile idiopathic arthritis: diagnosis, genetics, pathophysiology and treatment. Genes Immun. 2012;13:289-98. doi: 10.1038/gene.2012.3.

2. Grom AA, Mellins ED. Macrophage activation syndrome: advances towards understanding pathogenesis. Curr Opin Rheumatol. 2010;22:561-6. doi: 10.1097/01.bor.0000381996.69261.71.

3. Ravelli A. Macrophage activation syndrome. Curr Opin Rheumatol. 2002;14:548-52.

4. Bode SF, Lehmberg K, Maul-Pavicic A, Vraetz T, Janka G, Stadt UZ, et al. Recent advances in the diagnosis and treatment of hemophagocytic lymphohistiocytosis. Arthritis Res Ther. 2012;14:213. doi: 10.1186/ar3843. PubMed PMID: 22682420; PubMed Central PMCID: PMC3446494.
5. Arico M, Janka G, Fischer A, Henter JI, Blanche S, Elinder G, et al.; FHL Study Group of the Histiocyte Society. Hemophagocytic lymphohistiocytosis: report of 122 children from the International Registry. Leukemia. 1996;10:197-203.

6. Behrens EM, Beukelman T, Paessler M, Cron RQ. Occult macrophage activation syndrome in patients with systemic juvenile idiopathic arthritis. J Rheumatol. 2007;34:1133-8.

7. Bleesing J, Prada A, Siegel DM, Villanueva J, Olson J, Ilowite NT, et al. The diagnostic significance of soluble CD163 and soluble interleukin-2 receptor alpha chain in macrophage activation syndrome and untreated new onset systemic juvenile idiopathic arthritits. Arthritis Rheum. 2007;56:965-71. doi: 10.1002/art.22416.

8. Athreya $\mathrm{BH}$. Is macrophage activation syndrome a new entity? Clin Exp Rheumatol. 2002;20:121-3.

9. Ramanan $A V$, Schneider R. Macrophage activation syndrome - what's in a name! J Rheumatol. 2003;30:2513-6.

10. Henter JI, Elinder G, Ost A; The FHL Study Group of the Histiocyte Society. Diagnostic guidelines for hemophagocytic lymphohistiocytosis. Semin Oncol. 1991;18:29-33.

11. Ravelli A, Magni-Manzoni S, Pistorio A, Besana C, Foti T, Ruperto N, et al. Preliminary diagnostic guidelines for macrophage activation syndrome complicating systemic juvenile idiopathic arthritis. J Pediatr. 2005;146:598-604. doi: 10.1016/j. jpeds.2004.12.016.

12. Ravelli A, Minoia F, Davì S, Horne A, Bovis F, Pistorio A, et al.; European League Against Rheumatism/American College of Rheumatology/Paediatric Rheumatology International Trials Organisation. 2016 Classification Criteria for Macrophage Activation Syndrome Complicating Systemic Juvenile Idiopathic Arthritis. Arthritis Rheumatol. 2016;68:566-76. doi: 10.1002/art.39332.

13. Petty RE, Southwood TR, Baum J, Bhettay E, Glass DN, Manners $\mathrm{P}$, et al. Revision of the proposed classification criteria for juvenile idiopathic arthritis: Durban, 1997. J Rheumatol. 1998;25:1991-4.

14. Minoia F, Davì S, Horne A, Demirkaya E, Bovis F, Li C, et al. Clinical features, treatment and outcome of macrophage activation syndrome complicating systemic juvenile idiopathic arthritis: a multinational, multicenter study of 362 patients. Arthritis Rheumatol. 2014;66:3160-9. doi: 10.1002/art.38802. 


\section{Sažetak \\ USPOREDBA RAZLIČITIH DIJAGNOSTIČKIH SMJERNICA ZA DIJAGNOZU SINDROMA AKTIVACIJE MAKROFAGA KOJI KOMPLICIRA SISTEMSKI TIP JUVENILNOG IDIOPATSKOG ARTRITISA: ISKUSTVO JEDNOG CENTRA}

\section{Jelušić, M. Kronja, M. Frković, S. Sršen, S. Huljev Frkovići K. Štekić Novački}

Sindrom aktivacije makrofaga (MAS) potencijalno je smrtonosna komplikacija sistemskog tipa juvenilnog idiopatskog artritisa (sЛA) uzrokovana prekomjernim, ali neučinkovitim imunim odgovorom. Cilj ovoga istraživanja bio je usporediti dijagnostičku mogućnost smjernica HLH-2004 sa smjernicama za MAS iz 2005. godine, kao i s novim skupom klasifikacijskih kriterija iz 2016. godine u dijagnostici MAS-a koji komplicira sJIA. U istraživanje je bilo uključeno 35 djece u dobi od 1 do 18 godina kojima je postavljena dijagnoza sJIA prema kriterijima ILAR-a i koja su liječena u Klinici za pedijatriju, Zavodu za imunologiju i reumatologiju Kliničkog bolničkog centra Zagreb u razdoblju od 2009. do 2015. godine. Od 35 bolesnika kojima je postavljena dijagnoza sJIA bilo je 12 djevojčica i 23 dječaka koji su u vrijeme početka bolesti bili prosječne dobi $( \pm$ SD) 5,51 $\pm 3,65$ godina. Osmero bolesnika imalo je recidiv bolesti. Prema smjernicama iz 2005. godine dijagnoza MAS-a postavljena je u šestero $(17,1 \%)$ bolesnika sa sJIA. Prema novom skupu klasifikacijskih kriterija iz 2016. godine dijagnoza MAS-a postavljena je u četvero $(11,4 \%)$ bolesnika sa sJIA. Dijagnoza MAS-a nije postavljena ni u jednog bolesnika prema smjernicama HLH-2004. U našem istraživanju četvero od šestero bolesnika imalo je MAS na početku sJIA, a u preostalih dvoje on se pojavio tijekom recidiva bolesti. Dvoje bolesnika s MAS-om razvilo je punu kliničku sliku bolesti, dok ih je preostalih četvoro imalo nepotpuna klinička obilježja s manjim odstupanjem u laboratorijskim nalazima. Primjenom različitih dijagnostičkih smjernica utvrdili smo razliku u učestalosti MAS-a. Učestalost je bila nešto viša u usporedbi s postojećim istraživanjima, dok su ostala istraživana obilježja poput kliničkih karakteristika bila slična.

Ključne riječi: sindrom aktivacije makrofaga; artritis, juvenilni; dijete; Hrvatska; limfohistiocitoza, hemofagocitična 